COVER PAGE

\title{
War widows and revenge in Restoration England
}

\author{
Author name: Stewart Beale \\ Affiliation: University of Leicester \\ Postal address: 4 Kenilworth Court, Oxford. OX4 2AL
}

Telephone number: 07443537189

Email: sjb156@le.ac.uk

Manuscript word count: 11, 523

Abstract: This article examines petitions submitted by royalist widows to the House of Lords during the first few months of the Restoration. The husbands of these women had been tried and executed for treason during the 1640 s and 1650 s for their perceived loyalty to the royalist cause, prompting their spouses to demand retribution against their judges and jurors. As the Convention Parliament deliberated over the Act of Indemnity during the summer of 1660, these aggrieved widows were presented with an opportunity to ensure that the men they held responsible for their husband's deaths were brought to account. By assessing the petitioning strategies adopted by these women and the government's responses to their demands, the article throws light on a group of war widows who have received little scholarly attention. It is argued that whilst these women were largely unsuccessful, their efforts represent a significant aspect of female activism during the seventeenth century.

Key words: war widow; royalist; revenge; Restoration; Act of Indemnity 


\section{War widows and revenge in Restoration England}

Geoffrey Hudson's 1994 study of war widows and the county pension scheme sparked increased academic interest in the experiences of women widowed during the British civil wars. ${ }^{1}$ Since then, studies by David Appleby, Andrea Button and Hannah Worthen have thrown further light on the petitioning activities of war widows during the mid-seventeenth century. ${ }^{2}$ Drawing on petitions submitted to the House of Lords during the first few months of the Restoration, this article draws attention to a group of war widows who have received little scholarly attention. The husbands of these women had been tried and executed for treason during the 1640 s and 1650 s for their perceived loyalty to the royalist cause, prompting their spouses to demand retribution against their judges and jurors. As the Convention Parliament deliberated over the Act of Indemnity during the summer of 1660, these aggrieved widows were presented with an opportunity to ensure that the men they held responsible for their husband's deaths were brought to account. The exploits of these women and the government's responses to them invite an assessment of what was new of female petitioning activity at the Restoration, as well as the attitude of the restored monarchy towards private retribution and settlement.

By way of introduction it is necessary to consider the political context of the Restoration, as well as the subject of revenge more broadly. Charles II's return to England in May 1660 following nine years of continental exile was not achieved through force or strength of arms. Rather, he was invited back by Parliament to replace a faltering republican government that by the early months of 1660 lay on the verge of collapse. ${ }^{3}$ A month before his entrance into London - when his return to England appeared increasingly likely - Charles had issued a declaration from exile in the Low Countries, in which he promised clemency to all but a 
minority of men who had opposed the Stuarts during the civil wars. Known as the Declaration of Breda, the proclamation was intended to alleviate tensions regarding a restoration, by insisting that punishment would only be administered upon a select few chosen by Parliament. ${ }^{4}$ This caveat was to allow Charles the right to mete out punishment against the regicides: the men who had tried and executed his father. Reassured by his calls for peace, a Convention Parliament met at Westminster on 25 April in order to debate a settlement, and on 8 May Charles was pronounced king. The following day, the bill for an Act of Indemnity was entered into Parliament, in order to translate Charles's promise of forgiveness into official legislation. ${ }^{5}$ After three months of heated debate over who should and who should not be pardoned, the bill was passed on 29 August. Under the act, clemency was awarded to all but 33 men, of whom ten were executed in October 1660. A further twenty men were barred for life from holding public office. ${ }^{6}$

Charles's monopolization of vengeance and the perceived leniency of the Act of Indemnity towards former parliamentarians infuriated many of his supporters. ${ }^{7}$ Some who had expected to be rewarded for their loyalty were left sorely disappointed, whilst others, still nursing grievances from the past two decades, resented the wide-ranging clemency granted under the act. Yet as David Farr has recently argued, Restoration England was a far more vengeful place than contemporary commentators and some academics have allowed. Although relatively few of the regicides were subjected to public execution, many were handed stringent prison sentences, whilst those who fled abroad were hunted relentlessly by government agents. ${ }^{8}$ At least one individual, Charles Stanley, eighth earl of Derby, openly defied the Act of Indemnity when he ordered the execution of one of his wartime adversaries on the Isle of Man in $1663 .{ }^{9}$ At a more localised level, some royalists exploited the Restoration by harassing and violently confronting former parliamentarians and commonwealth-men. ${ }^{10}$ 
Set within this context of reconciliation and vengeance lay the exploits of almost a dozen royalist widows and orphans who petitioned the House of Lords in the summer of 1660. These petitions, located in the Parliamentary Archives, have not gone entirely unnoticed by historians. Both Maxwell Schoenfeld and James Hart have offered brief assessments of these women's exploits in their analyses of the House of Lords during the seventeenth century, though their cursory overviews largely concern Parliament's responses to these women, rather than female agency. ${ }^{11}$ More significantly, Andrea Button has studied the petitioning activities of the widows of those executed in the wake of Penruddock's Rising (1655), who coordinated themselves into a "pressure group" following the Restoration to appeal to both Parliament and Charles II for redress against those who had instigated their husband's deaths. ${ }^{12}$ Whilst insightful, Button neglected how the "network" of Penruddock widows was part of a broader context of widows' petitions for judicial vengeance at the Restoration.

The aim of this article is twofold. First, it profiles three female petitioners - Elizabeth Burley, Elizabeth, Lady Capel, and Mary Hewitt - in order to assess their motives for petitioning the Lords, and examines the strategies adopted to meet this end. In doing so, it illuminates a further facet of the petitioning tactics adopted by war widows during the midseventeenth century. Both Geoffrey Hudson and David Appleby have examined the strategies utilised by war widows who petitioned county Quarter Sessions for pensions during and after the civil wars. The language used in these petitions often presented the supplicant as an object of pity, emphasising both her hardship and, commonly, her role as a mother, in order to persuade magistrates that she was worthy of relief. Although most petitions adopted a deferential tone, some women were forthright in expressing their entitlements to welfare. ${ }^{13}$ Elsewhere, Hannah Worthen has demonstrated how royalist widows utilised the language of hardship and poverty, as well as demonstrating entitlement of their legal rights, in their petitions to the parliamentary Committee for Compounding for their sequestered estates during 
the 1640 s and 1650s. ${ }^{14}$ As shall be demonstrated, the petitions discussed here bear similarities with those submitted by war widows elsewhere, as well as striking differences. The second aim of this article is to consider the government's responses towards these widows. Although this has been briefly touched on elsewhere, a more thorough assessment of Parliament's handling of these women's complaints offers a greater insight into the government's attitude towards private settlement at the Restoration. It shall be argued that whilst the supplicants' demands for retrospective justice were largely unsuccessful, their efforts were neither ignored nor entirely without consequence.

The submission of these petitions was carefully planned to coincide with events inside Westminster during the spring and summer of 1660. All of the petitions considered in this article (unless otherwise stated) were presented to the House of Lords in late June and early July. Given that the Act of Indemnity was not passed from the Commons to the Upper House until 11 July, these female supplicants were thus attempting to gain a head start on proceedings by pushing their causes in the Lords before they had begun to officially debate the act. ${ }^{15}$ As such, their actions demonstrate an acute awareness of the goings on inside Parliament during this period.

Unlike the thousands of petitions presented to county Quarter Sessions on behalf of war widows seeking modest pensions during the mid-seventeenth century, the petitions considered here were mainly submitted by women drawn from the nobility and gentry, rather than the lower and middling sorts. ${ }^{16}$ Judicial revenge - at least in this context - was largely, though by no means exclusively, a privilege reserved for the elite. Despite the high status of these women, doubts remain as to whether they penned their own petitions. To be sure, these women were certainly literate - enough at the very least to sign their own supplications - and yet it remains 
likely that they relied on the advice and penmanship of professional scribes to draw up these documents for them. Rather than contain the "authentic" voice of these female petitioners, they therefore reflect what Jonathan Healey has described as "hybrid voices": a combination of the petitioner's experiences and the scribe's literary flair, and shaped by expectations of what the addressee (in this case the Lords) wanted to hear. ${ }^{17}$ An assessment of the language adopted by petitioners reveals a number of rhetorical strategies intended to persuade. This predominantly involved utilising imagery of female suffering and vulnerability, sacrifice for the royalist cause, the illegality of the Cromwellian judiciary, and cold-blooded murder. The petitions also demonstrate how retribution and recompense were inextricably interwoven.

The first of these petitions was submitted on 8 June on behalf of Elizabeth Burley. Her husband, Captain John Burley, had been executed in January 1648 after leading a failed attempt to rescue Charles I during his imprisonment at Carisbrooke Castle on the Isle of Wight. ${ }^{18}$ In her petition Elizabeth retold the chain of events which culminated in her husband's death. She claimed that his actions had been motivated by "a suddaine and strict restraint [that] was put upon his Ma[jes]ty in the moneth of December 1647, soe high, that none of his chaplaines, or servants, could have accesse to his person". ${ }^{19}$ This referred to the eviction of Charles's entourage from Carisbrooke Castle on the morning of 29 December, following the king's refusal to accept Parliament's proposals for negotiation. ${ }^{20}$ On hearing this order against the king, Burley:

fearing some evill might proceed from thence to the person of his Sacred Ma[jes]ty did (as in duty hee was bound) use the utmost of his endeavo[ur]s by beating up of drums in the said Island, thereby to give timely notice to the people, to appeare, \& preserve his Ma[jes]ty from that destruction, that afterward fell upon his sacred person.

Unfortunately for both Burley and Charles, the abortive rising was quickly suppressed. Burley was arrested and transported to Winchester, where he was tried for high treason by a commission of oyer and terminer directed by John Wilde, sergeant of law. After a trial lasting 
a "few houres", Burley was sentenced "to bee hanged, drawne, and quartered as a traito[u]r". This was, Elizabeth noted, "in the most barbarous manner that might bee, put in execution upon him". ${ }^{21}$

The court's decision to hang, draw and quarter Burley was a serious affront to his status as a gentleman. ${ }^{22}$ In her petition, however, Elizabeth appeared less concerned with the nature of her husband's death than with the legality of his trial. She particularly emphasised the heavyhandedness of the prosecutor, William Steele, who she claimed had subjected her husband to "violent prosecution". She also asserted that the jury had been deliberately selected by the commissioners in order to secure a guilty verdict. According to Elizabeth, her husband took particular issue with the presence of one Edward Hayes, who was selected to serve as foreman of the jury. Although she gave no indication as to why her husband opposed Hayes's presence on the jury, Elizabeth noted suggestively that he was elevated to the Hampshire bench soon after the trial.

Unsurprisingly, Burley's death was reported and interpreted in contrasting fashions by royalist and parliamentarian polemicists. In February 1648, the parliamentarian newsbook Perfect Occurrences felt obliged to deny claims that a spring of blood had appeared at the spot where Burley had been executed, by insisting that "it is nothing but the blood that ran from him which was not quite dryed the next morning, and gone as soone as any other could; there being no ground at all for the Report". ${ }^{23}$ This was likely an attempt to combat a number of royalist tracts published soon after Burley's death, which sought to fashion him as a martyr of the royalist cause. One pamphlet in particular, The Relation of the unjust proceedings against Captaine Burley (1648), contained a lengthy condemnation of Burley's trial. The pamphlet denounced those who had played a part in his execution for spilling "innocent blood", and praised Burley's virtuous character during the final hours of his life. According to the polemic, Burley impressed upon "his mournfull wife" that she "should never seeke revenge of those that 
were the unjust and cruel instruments of his death", and "took care for the preventing of all revengefull thoughts that might take fire from the flame of conjugall love towards him in the bosome of his wife that he left behind him". ${ }^{24}$ Intriguingly, the tract offers a further clue as to why Elizabeth may have sought retribution following the Restoration, despite her actions being at odds with the alleged final wishes of her husband. According to the pamphlet, Elizabeth was not only denied her request to retain her husband's estates, but was prevented by Wilde from recovering his dismembered body for burial. Ironically, the pamphlet concluded with a prophetic warning to Wilde, cautioning the judge that his treatment of Elizabeth might one day incite retribution: "I wish that wicked Serjeant to take heede, that that jeere of a poore distressed widdow, be not one day returned into his bosome in the like punishment". ${ }^{25}$

Whilst Elizabeth's petition omitted details of Wilde's rebuttals concerning her husband's corpse, it did acknowledge that his estates had been seized after his death. Incensed by a sense of injustice shown towards herself and her husband, it is unsurprising that Elizabeth saw the Restoration as an opportunity for vengeance. Her petition requested that "the innocent bloud of her deceased Husband may be inquired after, that justice may bee done upon the Judges, the Jurors, and Prosecutors for the murthering of yo[ur] pet[itione]rs husband". ${ }^{26}$ Having laid out a blanket accusation against all of the men involved in her husband's trial, Elizabeth singled out five of the judges by name to be exempted from the Act of Indemnity: John Wilde, Sir Henry Mildmay, John Lisle, Thomas Bowreman and John Hildesley.

As well as seeing the perpetrators of her husband's death suffer political punishment, Elizabeth also sought recompense for herself and her family. She further demanded that "reparation may bee made to yo[u]r pet[itione]r and her children out of the estates of those that were guilty", and, in a draft proviso annexed to the petition, requested permission to prosecute the aforementioned men in "any of his ma[jes]ties corts of record at Westm[inste]r". ${ }^{27}$ In this regard, retribution clearly had a financial purpose. The lack of surviving evidence ensures that 
it remains uncertain whether Burley died intestate, or whether Elizabeth received a jointure following his death. However, an entry in the Lords' Journal in June 1660 describing her as "poor" suggests that the widow had fallen into hardship following her husband's demise. ${ }^{28}$ As such, her husband's execution had not only deprived her of her spouse and his lands, but perhaps also her wealth and status. In this regard, her demands for retribution were not merely about punishing those who had executed her husband, but restoring her former livelihood. Elizabeth was well aware that should these men be pardoned under the Act of Indemnity, any chance of securing satisfaction from them would be lost.

In many regards, the rhetoric employed by Elizabeth in her petition was characteristic of conventional early-modern female petitioning norms, in which themes of female suffering, frailty and fatherless children were drawn upon in order to evoke feelings of sympathy within the addressee. ${ }^{29}$ By alluding to her "miserable \& distressed condicon"; her "foure children exposed to great want and miserie"; and that she had "lost a loving Husband", Elizabeth sought to fashion herself as an object of pity. Yet as well as deploying standardised tropes of female petitioning, Elizabeth's petition also drew from the language espoused in royalist martyrology. Within months of the execution of Charles I in January 1649, printed elegies, commemorative literature and sermons had propagated his public image as an innocent and Christ-like martyr, illegally sentenced to death by base rebels. ${ }^{30}$ Elizabeth's petition contained references to his "sacred Ma[jes]ty" Charles I, whilst she also described the "barbarous manner" of her husband's death, and the spilling of his "innocent bloud". Whilst her choice of language was deliberately emotive, it also suggests that Elizabeth was aware of the royalist martyr cult that had developed since the late 1640s. This is hardly surprising, since her husband was one of a number of martyrs celebrated in royalist print during the 1640 s and $1650 \mathrm{~s} .{ }^{31}$ In this regard, her choice of language, if not an attempt to draw parallels between the executions of her husband and Charles I, was designed to evoke imagery of royalist loyalty and sacrifice. In doing so, 
Elizabeth hoped to strengthen her claims for retribution by amplifying the crimes committed by her husband's executioners.

Similar rhetorical strategies were present in the petition of Elizabeth, Lady Capel. Her husband, Lord Arthur Capel, had served as commander-in-chief of the royalist forces in East Anglia during the Second Civil War, and was captured following the royalist surrender at Colchester in August 1648. Parliament initially voted to limit Capel's punishment to banishment, but following Pride's Purge in December 1648 and the execution of Charles I the following month, he was soon brought before the High Court of Justice. This was the same court that only six weeks earlier had sanctioned the execution of Charles I. ${ }^{32}$ Tried and adjudged guilty of high treason, Capel was beheaded on 9 March outside Westminster Hall along with two other royalist nobles; James, duke of Hamilton and Henry Rich, first earl of Holland. ${ }^{33}$

Styling herself as a "disconsolate widdow", Elizabeth opened her address by describing her husband's loyalty to Charles I, as well as his "zeale for the defence of the lawes of the land". This commitment towards both monarch and common law sat in juxtaposition to her description of the events of 1648 , in which her husband:

after the vote of no more Addresses to the King, his ma[jes]tie being shut up prisoner in Carisbrooke Castle, the Lords House violently taken away \& all honest \& well affected persons of the House of Commons eyther thrust or kept out of the House by force [was] arraigned and condemned to dye by a pretended High Court of Justice. ${ }^{34}$

By discrediting the legitimacy of the court, Elizabeth claimed that the sentence procured against her husband was "contrary to the knowne lawes of the land [and] the Priviledges of the Peeres of this Realme". In doing so, Elizabeth undoubtedly sought to remind the Lords of the abhorrent and arbitrary treatment of a fellow peer. This tactic had earlier been used by Charlotte, countess dowager of Derby, in her petition to the Lords on 9 June. ${ }^{35}$ Her husband, James Stanley, seventh earl of Derby, had been executed for treason in 1651 for his loyalty to 
the royalist cause. As John Callow and Katharine Walker have demonstrated, both Charlotte and her son, Charles, eighth earl of Derby, embarked on a campaign after the Restoration to bring Stanley's condemners to trial, and to win back their estates confiscated during the civil wars. $^{36}$

Elizabeth also maintained that her husband's execution had violated "the Articles of Agreement interchangeably signed by the Commissioners of the Assaylants \& Defendants at the siege of Colchester". ${ }^{37}$ This argument - posited by Capel during his trial, and later recounted by royalist polemicists - concerned the terms by which the royalist commanders had surrendered to the parliamentarian general Lord Thomas Fairfax in 1648. Technically, Capel and his fellow commanders had surrendered to Fairfax "at mercy": a harsh term which did not guarantee the vanquished quarter. As such, Fairfax could subject the royalist prisoners to any punishment he deemed fit, without reneging the terms of surrender or violating the articles of war which governed the treatment of military prisoners. ${ }^{38}$ When Fairfax handed the prisoners over to Parliament to be tried by civil rather than military law, however, Capel argued that the terms of surrender had been violated. During his trial, he also (incorrectly) insisted that he had surrendered to Fairfax at quarter, a more lenient term that guaranteed the prisoner his life. ${ }^{39}$ For their part, Parliament maintained that the terms of surrender agreed at Colchester freed Capel "from the execution of the sword but not any protection from the judiciall proceedings of a civill court". ${ }^{40}$ Eager to make an example of one of the men whom they held accountable for plunging the country into a second civil war, it is little surprise that Parliament proceeded with the trial in spite of Capel's protests. Evidently, one's outlook towards the trial hinged on one's personal interpretation of the terms of surrender, and it is easy to understand why Elizabeth (not to mention royalists in general) viewed her husband's death as a violation of those terms. This, along with her further insistence that her husband had been "barbarously murdered contrary to the solemne ingagement of the Army", should not, therefore, be viewed 
as a deliberate attempt to spin the events of her husband's surrender, nor be mistaken for female ignorance of military codes of conduct. ${ }^{41}$ Rather, it should be seen as a steadfast refusal on her behalf to accept that her husband's execution had been just.

Unlike Elizabeth Burley, the petition of Elizabeth Capel contained no request for monetary recompense. This was likely because Capel was far more financially secure. Following her husband's death the House of Commons had allowed Elizabeth to retain much of her family's property, and at her own death in 1661 she was sufficiently wealthy to bequeath $£ 5000$ to each of her two daughters, as well as expensive household and personal items including furniture, portraits and jewellery. ${ }^{42}$ Nor did Elizabeth focus her demands for retribution on any one particular individual. Rather, she appealed to the Lords that "all those who have had a hand in this notorious wickednesse may for the glory of God, the Honour of the English Nation \& for terrour to all such wicked men, be brought to condigne punishment". ${ }^{43}$ In this regard, the enactment of revenge was a necessary action needed to satisfy both God and the nation, as well as act as a deterrent to others.

Although Elizabeth's call for retribution might be viewed as a rational response of a bereaved widow, her call for vengeance against her husband's condemners directly defied the wishes of her deceased spouse. Speaking upon the scaffold shortly before his execution, Arthur Capel expressed forgiveness to all those who had sentenced him to death. ${ }^{44}$ This is perhaps unsurprising, since public pardoning by the condemned was a convention of the early-modern scaffold speech. ${ }^{45}$ Indeed, even Charles I was reported to have expressed forgiveness to the regicides shortly before his death. ${ }^{46}$ Whilst we may therefore question how far this final act of Christian pardoning represented Capel's true feelings towards his condemners, he does appear to have echoed similar sentiments in private. George Morley had served as chaplain to the peer during his imprisonment, and had witnessed the final visit paid by his wife and eldest son, 
Arthur, on the morning of his death. According to Morley's account, Capel commanded his wife and son never to revenge his death, but to "forgive his enemies". ${ }^{47}$

Arthur Capel went to his grave having both publically and privately exonerated the men responsible for putting him there. Seen in this light, Elizabeth's pleas for revenge during the summer of 1660 require explanation. Although her inability to forgive the republic's judiciary was far from irrational, her desire to seek retribution may also have been shaped by her own wartime experiences. During the siege of Colchester in 1648, Parliament ordered the arrest of her sixteen year old son in an attempt to pressure his father to surrender. According to a royalist newsbook, the boy was "ravist from his mothers arms", and, being taken to Colchester, was placed "before the mouth of their Enemies cannon, that so in case any shot was made the Innocent Child might first lead the dance of death" ${ }^{48}$ Whilst the treatment of the child was perhaps exaggerated by royalist propagandists, the episode underlines the exceptionally nasty nature of the siege of Colchester. Elizabeth's trauma at the arrest of her son was heightened by her own pregnancy. According to a further account, the "sudden \& unexpected inhumanity caused her (as is said) to fall into present travail of Child-birth, to the great hazard of her life". ${ }^{49}$ Two days before her husband's execution, Elizabeth had unsuccessfully lobbied parliament to spare his life. Although the Commons later discharged parts of her family's estate from sequestration, this consolatory gesture was evidently insufficient to quench her thirst for vengeance..$^{50}$

\section{IV}

On 21 June 1660 the petition of Mary Hewitt, the second wife of the royalist minister and conspirator Doctor John Hewitt, was read in the Lords. Hewitt was tried by the High Court of Justice in June 1658 after becoming embroiled in an alleged plot to raise a royalist force in London. ${ }^{51}$ Found guilty of treason, he was beheaded at Tower Hill on 8 June $1658 .{ }^{52}$ Unlike 
the other royalist widows who have so far been considered, Mary did not wait until the Restoration before seeking justice for her husband's death. On 17 March 1659 she petitioned parliament requesting retribution against the men who had condemned her husband to die. ${ }^{53}$ She may have hoped that the death of Oliver Cromwell in September 1658, followed by the succession of his son Richard, represented a sufficient regime change to attempt a prosecution. Although her claims were dismissed, the restoration of the Stuart monarchy the following year encouraged Mary to chance her luck for a second time.

Rather than style herself as a "widow" or "relict", Mary presented herself to the Lords as "one of the Daughters of the right hon[oura]ble Robert late Earle of Lindsey deceased". 54 She may have hoped that her father's title would have enhanced her standing before the peers, though it is also significant that Lindsey himself was a royalist martyr, who had died at the battle of Edgehill in October 1642. In an attempt to fashion herself as an object of pity, Mary drew from similar tropes utilized by both Burley and Capel, noting her "unspeakable griefe", "irreparable loss" and "ffatherles children". She likewise provided a damning denunciation of the legality of her husband's trial, blasting the High Court of Justice as "Tyrannicall" and a "bloody court". The men who had sentenced her husband were labelled "presumptuous murderers", who had acted "contrary to the lawes of this land". Like Elizabeth Capel, Mary insisted that retribution against her husband's judges, jurors and executioners was not simply just in its own right, but a necessary act to deter "all men from the like villainies". 55

A month before submitting her supplication to the Lords, Mary had petitioned the House of Commons with similar aspirations of revenge. ${ }^{56}$ Substantially longer in length and more colourful in language, this petition contained considerable detail later omitted from her petition to the Upper House. Whereas her petition to the Lords failed to name her adversaries (simply labelling all those who had played a role in her husband's death as "presumptuous murderers"), her petition to the Commons cited Oliver Cromwell - a "Bloody Tyrannical 
pretended Protector" - as one of the chief instigators of Hewitt's execution. The petition also demanded that John Lisle, who had presided over the trial, be exempted from the Act of Indemnity, and that recompense be afforded to her from six of the commissioners who had served during the hearing. The punishment of these men was not simply an important act of public justice, she insisted, but an act which bore religious significance. As Mary noted, "the effusion of Innocent Christian Blood... cries aloud for vengeance". 57

The religious sentiment expressed in Mary's petition is hardly surprising. Numerous Biblical references could be drawn upon to support her cause for vengeance, some of which had been advanced by her husband during his trial in 1658 . Having learned that he was to be sentenced to death, for instance, Hewitt cited Joel's threat to Egypt: "Egypt shall be a desolation, and Edom a desolate wilderness, for their violence against the children of Judah, because they have shed innocent bloud in the land". ${ }^{58}$ As well as utilising religious imagery to bolster her claims for justice, Mary's insistence that the "innocent blood" of her deceased husband demanded retributive action - a point that had earlier been voiced by Elizabeth Burley - might be viewed as a deliberate attempt to evoke the concept of blood guilt. Patricia Crawford and Stephen Baskerville have persuasively argued that the notion of avenging the spilling of innocent blood carried strong currency during the civil wars. It was used by supporters of both sides to justify military action during the 1640 s, and was later used as a key argument against Charles I during his trial in $1649 .{ }^{59}$ Given the centrality of blood guilt in justifying judicial action against the king, it is perhaps unsurprising that these women sought to utilise the same concept against their husbands' condemners. In doing so, the insinuation was clear: the murder of their spouses in cold blood demanded retrospective retaliation, and it was Parliament's responsibility to ensure that those culpable were punished accordingly.

The two petitions submitted by Mary not only differed in content, but also the medium in which they were presented. Whereas her supplication to the Lords was in manuscript form, 
the petition submitted to the Commons was printed. The format of this petition - printed on a single sheet with few "decorative devices" - suggests that it was likely intended for private circulation amongst MPs, rather than distributed publically to garner popular support for her appeal. ${ }^{60}$ That said, news of Mary's petitioning activity at Westminster soon reached the provinces. On an unspecified day in May 1660, the Worcestershire gentleman Henry Townshend recorded in his diary that:

Dr Hewit's widow petitioned the parliament for justice against the illegal president Lisle and that he may be as a murderer excepted from pardon in the act of oblivion. And that Titchborne, Ireton and Pack, aldermen, Serjeant Cooke, John Barkstead, and John Phelps, and the rest may make her due reparation for her husband's death. ${ }^{61}$

Townshend's intimate knowledge of Mary's petition indicates that he had seen a copy of the document before copying it into his diary. Since Townshend never served as an MP, and, as his recent editors have asserted, regularly received printed news from his friends in London, it seems plausible that he was sent a copy of the document from an acquaintance in the capital. ${ }^{62}$ That he felt obliged to copy it into his diary further suggests that the activities of these women aroused public interest.

Having profiled these three women, it is necessary to briefly place their petitioning activities within a broader context of supplications submitted to the House of Lords during the summer of 1660. Widows of executed royalists were not the only petitioners to appeal to the Lords during the first few months of the Restoration. The Upper House also received supplications from the children of former cavaliers. Petitions submitted on behalf of the daughters of James, duke of Hamilton (29 June), and the children of Henry, earl of Holland (20 June), and Sir Henry Slingsby (21 June), were all read in the Lords, requesting justice for their fathers' deaths. So too were petitions submitted by the siblings of Sir Henry Hyde (21 June), a royalist diplomat 
beheaded in 1650, and the father and brother of the royalist conspirator John Gerard (27 June), who was executed in 1654.

Nor were demands for retribution solely motivated by the death of a loved one. On 26 July the Lords read the petition of Bridget Wright, widow of Robert Wright, former bishop of Lichfield and Coventry, requesting that the parliamentarian commander Sir William Brereton be excluded from the Act of Indemnity. The 82-year-old Robert had garrisoned his episcopal residence at Eccleshall in Staffordshire for the king at the outset of the war, but died of natural causes in 1643 during an eight-week siege of the castle by Brereton's forces. ${ }^{63}$ With the besieged unable to bury his body, his corpse laid uninterred in the garrison for five weeks. It was later removed by royalist soldiers as they attempted to evacuate the castle, but was ditched in the castle grounds as they attempted to escape pursuing parliamentarian troops. ${ }^{64}$

Bridget's indictment against Brereton was motivated not so much by the fate of her husband, as by the events which followed the surrender of the castle. Having managed to escape from the garrison during the same botched evacuation which led to her husband's corpse being unceremoniously dumped, Bridget entrusted its defence into the hands of a tiny force consisting of no more than eleven men. ${ }^{65}$ The following day, overwhelmed by Brereton's superior numbers, the garrison capitulated, and the besieged were permitted to march out bearing only their arms. When Brereton's forces entered the castle, they found 40 barrels of beer, as well as "Rich app[ar]ell, money, plate \& other thinges (as most thought) to the valewe of Ten Thowsand poundes". ${ }^{66}$ Much to Bridget's dismay, much of this was quickly requisitioned for the parliamentarian war effort. Bridget - who herself claimed to have been a victim of the siege, after receiving a shot in the shoulder whilst working on the garrison's defences - claimed that Brereton's repossession of her belongings transgressed the terms of the garrison's surrender, in which he had agreed to return her goods, plate and money. To add insult to injury, Parliament later awarded Eccleshall Castle to Brereton in 1646 for his loyal service during the war. 
Desperately short of income, Bridget claimed to have spent five years in prison for debt during the 1650s. She requested satisfaction for her goods, and that Brereton be exempted from the Act of Indemnity. ${ }^{67}$

Nor were appeals for retribution confined to those who resided in England. On 15 June Martha Hatt, alias Arundel, petitioned the Lords concerning the loss of her estates in Ireland during the rebellion of $1641 .{ }^{68}$ Her husband, Simon Hatt, had served as a cornet in Sir Charles Coote's regiment until July 1643, when he succumbed to wounds sustained whilst fighting the Irish rebels. Martha's own wartime ordeals, recounted in a printed petition presented to Parliament in 1659 , reads like a series of unfortunate events. ${ }^{69}$ Parts of it may have been embellished for dramatic effect, but her tribulations further highlight many of the hardships faced by women in Ireland during the $1640 \mathrm{~s}$ and $1650 \mathrm{~s} .{ }^{70}$ In November 1641 Mary's home near Mullingar was attacked, plundered and torched by 140 rebels. Having fled the carnage, Martha and her four children eked out an existence over the next five years by moving between English garrisons. In 1646 she returned to the wreckage of her house in order to recover what salvageable goods she could carry, but was later robbed on the road as she travelled to a relative's house in Dublin. Having reached her destination and finding herself unable to secure a lawsuit against her accoster, Martha then suffered the death of three of her children. Worse was to follow.

In 1652 Martha began an eight-month courtship with one George Arundel, a selfproclaimed bachelor from Launceston in Cornwall, who boasted to be worth $£ 100$ per year. Martha's vulnerability appears to have made her easy prey for men like Arundel, and upon their marriage in December 1652, he proceeded to waste her goods, mortgage her leases, and "abused her person". It also transpired that Arundel had a wife of thirteen years awaiting his return in Launceston. Fearing that she might be accused of adultery, Martha left her husband soon after discovering the truth of his previous marriage, but, desperately short of money, was 
forced to pawn her apparel for food. She was also forced to sell the debentures of her first husband, worth $£ 150$, at the reduced rate of $18 \mathrm{~d}$ per pound. Martha claimed that this practice had become common amongst "many thousands" of poor soldiers, widows and orphans in Ireland, who, she insisted, were forced "to sell their Arrears, the price of their blood for a Mess of pottage". ${ }^{71}$

Martha's request that Parliament establish an independent committee to adjudicate her case was denied. This unfavourable verdict in 1659 prompted her to petition the Lords following the Restoration. Whilst much of the lurid detail contained in her petition of 1659 was omitted in her second supplication, Martha provided the peers with a brief account of the attack on her home in 1641. She further protested that what remnants of her estate that had survived the rebellion had subsequently been detained from her by Sir Theophilus Jones. A younger brother of the parliamentarian officer Michael Jones, Sir Theophilus served as a lieutenantcolonel in Lord Conway's regiment during the early 1640s, and was later appointed temporary governor of Dublin when Cromwell besieged Drogheda in 1649. He was dismissed from the army in the summer of 1659 , which may explain the timing of Martha's first petition to Parliament around September that year. ${ }^{72}$ Sir Theophilus was restored to favour following the Restoration, however, and Martha's pleas for recrimination against him were quickly rejected by the Lords. In a second petition addressed to the Upper House on 4 July, Martha instead requested relief to pay for the costs of travel to Ireland, where she hoped to continue her suit against him. ${ }^{73}$

\section{VI}

This penultimate section examines the government's response towards these women. Following their readings in the Lords, the petitions of Elizabeth Burley, Mary Hewitt, Bridget Wright, Martha Hatt and the Slingsby children were passed to the Committee for Petitions for 
consideration. This committee met in the Painted Chamber at Westminster Palace. By the time that the Convention Parliament was closed in November 1660 a total 63 men had been appointed to the Committee, though both its average attendance and regular attendees remain uncertain. The Committee consisted of both former royalists and parliamentarians in more-orless equal measure and, during the early stages of the Convention Parliament at least, appears to have been chaired by the earl of Pembroke. ${ }^{74}$ That the royalist marquis of Dorchester reported from the Committee to the Lords on at least three separate occasions regarding the proceedings in the cases of Elizabeth Burley and Mary Hewitt suggests that he too played a leading role in the adjudication of these disputes. ${ }^{75}$

Counsel was assigned to the petitioners, and witnesses for both the prosecution and defence were summoned to give evidence. ${ }^{76}$ Little in the way of direct testimony appears to have survived, though an order book and a book of proceedings for the Committee provides some insight into events inside the Painted Chamber during these months. ${ }^{77}$ Witnesses raised to speak on behalf of Elizabeth Burley were ordered to appear before the Committee on 15 June 1660. This date was pushed back a number of times over the following days, presumably on account of the high volume of business handled by the Committee during this period, and perhaps to allow the prosecution additional time to raise witnesses. When proceedings began on 3 July, the Committee appeared pressed to determine the truth surrounding three interrelated details concerning the nature of her husband's uprising and trial. First, whether the rising on the Isle of Wight had been carried out on behalf of the king; second, whether the jury selected to try Burley had been deliberately packed; and third, whether it had been designed by the judges to have him executed before a commission had been sent down from Parliament in London. $^{78}$

The first of these points proved easy to demonstrate. One witness, Katherine de Luke, claimed to have been present in Charles I's chamber at the time that his entourage was evicted 
from Carisbrooke Castle, and that king "wished his friends should be acquainted with it to come to his reliefe". Meanwhile, Robert Green testified to being in Newport on the morning of the uprising, where he was informed that the king had been confined, and that he had "asked if his friends would not rise for him" ${ }^{79}$ Whilst it was evident that the uprising had been instigated at Charles's request, demonstrating that Burley had been illegally sentenced to death proved more difficult. Although one witness confirmed that Burley had been denied counsel during his trial, and that he had taken issue with the composition of the jury, evidence regarding the arbitrary proceedings of the judges and jurors proved underwhelming. It is perhaps for this reason that on the same day that witnesses were examined, the Committee reported to the Lords that "what was done [Burley's execution], was done by Commission from both Houses of Parliament, and in such a judicial Way as all Justices of Assize and other Persons acted in those Times". ${ }^{80}$ Witnesses for the defence were summoned to appear before the Committee on 22 July, though no further testimony from the hearing appears to have survived. ${ }^{81}$

The case of Mary Hewitt opened on 14 July. 26 witnesses were summoned before the Committee to provide evidence on behalf of the widow, whilst the men who had sat at her husband's trial were also obliged to attend. Most appear to have followed the Committee's orders, though both John Biscoe and John Stone were noted for their absence. They were granted a further four days to appear before the Committee, or risk facing the displeasure of the Lords. Although no witness testimony has survived from the hearing, an abridged transcript of the case for the prosecution was recorded in the Committee's summary of proceedings. ${ }^{82}$ The case was presented by the royalist judge Sir William Morton, who may have been appointed by the Committee to act on behalf of Mary. The prosecution argued that the High Court of Justice that had sentenced Hewitt to death in 1658 had been erected contrary to common law, and, that by serving his king, Hewitt was guilty of nothing more than an act of virtue, rather than treason. In legitimating action against Hewitt's condemners, the prosecution 
further argued that the punishment of arbitrary judges had historic precedent, for 44 judges had been sentenced to death during the reign of King Alfred for illegal malpractice. This included the hanging of one Cadwin, who had put a man to death without the consent of the whole jury, and Athelston, who had condemned someone to die for an offence not capital. The prosecution concluded that "persons may not be protected by law who would afford no law to others". 83

Despite these initially favourable proceedings, any hopes harboured by these widows of securing a favourable verdict were soon quashed. On 27 July Charles II appeared before the Lords in order to demand a speedy resolution to discussions over the Act of Indemnity. He insisted that the Lords set aside all feelings of retribution towards former parliamentarians and commonwealth-men, "to make them good subjects to me, and good friends and neighbours to you". "Therefore", he continued, "I do earnestly desire and conjure you to depart from all particular animosities and revenge, or memory of past provocations, and that you will pass this Act, without other exceptions, than of those who were immediately guilty of that murder of my father". ${ }^{84}$ Heeding his words, the Lords ordered on 3 August that the Committee for Petitions suspend meeting until after the Act of Indemnity had been passed. Three days later, the peers ordered "That all Provisos whose Matter is of Private Concernment shall be left out of this Bill". ${ }^{85}$ The cases of Elizabeth Burley and Mary Hewitt were subsequently dropped.

The demands of Lady Capel and the countess of Derby, as well as those of the children of the earl of Holland and the duke of Hamilton, were handled somewhat differently. As former peers, the Lords viewed their deaths as an affront to their own status, and were particularly eager to see those responsible punished. Their cases were referred to the Committee for Privileges, who ordered all those who had signed the peers' death warrants to appear before them. Whilst some such as Edmund Waring and George Langham readily admitted to signing the warrants, others were more restrained. Sir John Thoroughgood pleaded that he had "disented from the sentence of death", whilst Samuel Moyer claimed that he did "nothing 
malitiously nor wilfully but [was] misled by knowing men of law". ${ }^{86}$ After deliberation, the Lords decided to allow the nearest living relative of each of the dead peers who currently sat in the Upper House to select one individual to be exempted from the Act of Indemnity, as retribution for their losses. Arthur Capel, son and namesake of Lord Capel, selected Edmond Waring, whilst the earl of Derby picked Colonel Thomas Croxton ${ }^{87}$ It is significant that despite the petitioning activities of these women, the act of selecting an individual to be subjected to retributive action was - publically, at least - denied them in favour of their male relatives. The subsequent bill was blocked by the Commons, however, who on 21 August noted that since "they [the Commons] do not insist upon the shedding of Blood upon the Account of the Death of Commoners... they hoped their Lordships would not have the Sacrifice of the King's Blood to be mingled with any other Blood" ${ }^{88}$ The Lower House did, however, agree to perpetually bar from office all those who had sat in any of the high courts of justice.

Some of the men singled out for retribution by these widows were exempted from the Act of Indemnity when it was ratified by Charles II on 29 August. John Lisle, for example who was singled out by Mary Hewitt - fled the country soon after the Restoration, having been denied pardon. He was tracked down and assassinated by royalist agents in Switzerland in 1664. ${ }^{89}$ Of the other men mentioned in Mary's petition, Robert Tichborne narrowly avoided execution, but was sentenced to life imprisonment, whilst John Ireton and Christopher Packe were barred for life from holding office. John Barkstead fled to the continent after he was exempted from the act, but was later captured in the Netherlands and executed in 1662. Another man who fled, John Phelps, managed to avoid capture, and is presumed to have died in Switzerland. ${ }^{90}$ Meanwhile, Sir Henry Mildmay, one of the commissioners at the trial of John Burley, was sentenced to life imprisonment, whilst another, John Hildesley, a Hampshire JP, was removed from the county bench after the Restoration. ${ }^{91}$ It should be noted, however, that the punishments meted out against Lisle, Mildmay, Titchborne, and Barkstead - as well as the 
pursuit of Phelps - was because they had served at the trial of Charles I. It is therefore implausible to link their fates after the Restoration with the actions of these widows. Indeed, it is perhaps more telling that John Wilde, who had served as the head judge during the trial of John Burley, was pardoned in 1660, whilst John Glynne, who had conducted the trial of the rebels of Penruddock's rising in 1655, was knighted and made king's serjeant in November $1660 .{ }^{92}$

Although these widows were largely unsuccessful in their pursuit of judicial retribution, their families were, on the whole, generously recompensed by the royalist government. In December 1660, Elizabeth Burley was granted a yearly pension of $£ 50 .{ }^{93}$ Meanwhile, in 1661 , shortly after her death, Elizabeth Capel's son Arthur - who as a child had been paraded before the walls of Colchester - was created earl of Essex, and in doing so took the title of the former parliamentarian commander-in-chief Robert Devereux, who had died in 1646. As Ronald Hutton has asserted, this in itself was a minor act of retribution, for Devereux had been the recipient of some of Capel's confiscated estates during the 1640s. ${ }^{94}$ The following year, a royal pension of $£ 100$ was awarded to John Hewitt, son and namesake of his father, although in 1665 he complained that this had fallen into arrears. ${ }^{95}$ Not all were so fortunate, however, for in 1666 the son of Bridget Wright died a debtor in the king's bench prison. ${ }^{96}$

Tim Harris has argued that the execution of ten of the regicides in October 1660 "did enough to satisfy the nation's thirst for revenge without instigating the type of bloodbath that might have been counterproductive". ${ }^{97}$ Whether it did enough to satisfy the appetites of the women presented in this article remains a moot point. Given that Elizabeth Burley had explicitly requested to be compensated from the estates of her husbands' condemners, a token of recompense in the form of a royal pension may have done enough to appease her. On the other hand, the case of Elizabeth, Lady Capel suggests that some royalists carried their feelings of retribution to the grave. Following her death in 1661, a tombstone erected on behalf of 
herself and her husband in the parish church of Little Hadham, Hertfordshire, intended to show for posterity that Lord Arthur Capel had been "murdered for his loyalty to King Charles the First". ${ }^{98}$

VII

Despite the largely unsuccessful attempts of these women to bring their husbands' condemners to account, their efforts represent a distinctive and important feature of the petitioning activities of war widows during the British civil wars. To be sure, parliamentarian widows had proved equally vindictive during the 1640s. Two years after the death of the parliamentarian Sir Henry Foulis in 1643, for instance, his widow Mary petitioned the Yorkshire Committee seeking action against Sir Ingram Hopton, who had been awarded the revenue from her estates during the royalist occupation of Cleveland in 1643-4. ${ }^{99}$ Yet assertive attempts to influence the shape of the Act of Indemnity were unique to these royalist widows, and their efforts represent a significant aspect of female activism during the seventeenth century.

The women presented in this article possessed a striving for vengeance that was inextricably linked to their own extraordinary experiences of the civil wars. For some, the deaths of their husbands had been compounded by the dispossession of their estates, possessions and wealth. In this regard, revenge was motivated by multiple factors. Whereas Charles II was driven by a thirst for regicidal blood to satisfy the memory of his late father, the actions of these women were as much prompted by a desire for recompense as a longing to unleash the executioner's axe. Public acknowledgement of their husbands' sacrifices and recognition of their own wartime ordeals may also have played their part. For the women whose husband's had been publically executed during the 1640 s and 1650 s, a gesture of recognition from Parliament and the Crown to repair their tarnished family honour and to vindicate the status of their husbands might have been as equal an incentive as simply bringing their spouses' 
condemners to account. Revenge was likely motivated by reward, for relief, and for restoration, as much as it was for retribution.

The exploits of these women stand in contrast to the thousands of war widows who petitioned county Quarter Sessions for relief during the mid-seventeenth century. Their actions demonstrate a deliberate attempt to exploit the political uncertainty caused by the restoration of the Stuart monarchy. Their petitions combined standardised rhetorical descriptions of widowhood and female vulnerability with an aggressive condemnation of the legality of the republic's courts, insistence on the innocence of their husbands, and accusations of coldblooded murder. The high status of these women and the casting of their husbands as martyrs of the royalist cause undoubtedly served to enhance their petitioning authority, encouraging them to be bold and forthright in their demands for revenge. Moreover, by drawing from the rhetoric of the royalist martyr cult, these women sought to enhance their demands for vengeance by evoking imagery of royalist loyalty and sacrifice. That most of the demands of these widows were ultimately overlooked by the Restoration regime should not detract from their attempts, but further suggests that for the sake of political stability during the summer of 1660, public indemnity and pardoning were more beneficial to Charles II than outright retribution. ${ }^{100}$

Although the passing of Act of Indemnity in August 1660 curbed demands for retrospective justice, it did not extinguish them all together. In March 1662 Elizabeth Hudson petitioned Charles II for a lease of land which had formerly belonged to one Major Francis Underwood, a parliamentarian captain who she alleged had "butchered" her husband, Dr Michael Hudson, to death at Woodcroft House in $1648 .{ }^{101}$ That same month, Elizabeth submitted a second petition to the king requesting a grant of $£ 500$ from Henry Field, a former chaplain in the earl of Manchester's regiment, after he had been fined for seditious preaching by the King's Bench. Elizabeth maintained that Field had turned her out of doors during the 
1640s, and had "hyred men and was himselfe at the murdering" of her husband. ${ }^{102}$ Despite transgressing the Act of Indemnity, Elizabeth was awarded a royal pension of $£ 50$, though a year later she complained that it had fallen into arrears. ${ }^{103}$

Nor did the exploits of royalist widows prove to be the last time during the seventeenth century that widows sought to exploit a shift in political power in order to petition for judicial retribution. When William of Orange landed at Torbay in November 1688 he was allegedly greeted by more than fifty women whose husbands had been sentenced to death by George Jeffreys in the wake of Monmouth's rebellion three years previous, demanding retribution against the judge. ${ }^{104}$ The following year, a printed petition addressed to parliament on behalf of "a Thousand and more" widows and orphans from the counties of Dorset, Somerset and Devon complained against the draconian punishments meted out by Jeffreys. The petition requested that the judge "may be brought down to the Counties aforesaid, where we the good Women in the West shall be glad to see him; and give him another manner of wellcome than he had there three Years since". ${ }^{105}$ Although the petition was likely a mocking piece of propaganda aimed at discrediting Jeffreys rather than a genuine attempt to bring him to account, it nevertheless underlines how the change of political regime could foster opportunities for retrospective justice and the settling of scores. In 1688 as in 1660, widows were quick to exploit such opportunities.

\section{Acknowledgements}

I am grateful to Dr Andrew Hopper and Dr David Appleby for commenting on an earlier draft of this paper.

\section{Notes}

\footnotetext{
${ }^{1}$ Hudson, "Negotiating for Blood Money”, 146-169.
} 
2 Appleby, "Unnecessary Persons?", 209-211; Button, "Royalist Women Petitioners", 53-66; Worthen, "Supplicants and Guardians", 1-13.

${ }^{3}$ See Hutton, The Restoration.

${ }^{4}$ English Historical Documents, viii, 57-58.

${ }^{5}$ Statutes of the Realm, v, 226-234.

${ }^{6}$ Harris, Restoration, 47-48.

${ }^{7}$ Miller, After the Civil Wars, 161; Seaward, The Restoration, 1660-1688, 36.

${ }^{8}$ Farr, Major-General Thomas Harrison, 257-258.

${ }^{9}$ Callow, "The Limits of Indemnity", 199-216.

${ }^{10}$ Hutton, The Restoration, 136; Appleby, "Veteran Politics", 329-330; Hopper, "The Farnley Wood Plot", 292;

Roberts, "Public or Private?", 174; Scott, Original Memoirs, 162-198.

${ }^{11}$ Schoenfeld, Restored House of Lords, 190-191; Hart, Justice Upon Petition, 237.

12 Button, "Royalist Women Petitioners", 53-66.

${ }^{13}$ Hudson, "Negotiating for Blood Money", 146-169; Appleby, “Unnecessary Persons?”, 209-221.

${ }^{14}$ Worthen, "Supplicants and Guardians", 1-13.

${ }^{15} \mathrm{LJ}$, xi, 87 (11 July, 1660).

${ }^{16}$ Hudson, "Negotiating for Blood Money", 154.

${ }^{17}$ Healey, First Century of Welfare, 93.

18 Jones, The Royal Prisoner, 54-55; Henderson and Trombley, "Burley, John (d. 1648)"; A Designe by Captain Barley.

${ }^{19}$ Parliamentary Archives [PA], HL/PO/JO/10/1/285.

${ }^{20}$ Jones, The Royal Prisoner, 51-53.

${ }^{21} \mathrm{PA}, \mathrm{HL} / \mathrm{PO} / \mathrm{JO} / 10 / 1 / 285$.

${ }^{22}$ Little is known of Burley prior to his death, although in his list of royalist martyrs William Winstanley described him as a "Gentleman of the Isle of Wight". Winstanley, The Loyall Martyrology, 12.

${ }^{23}$ Perfect Occurrences (4-11 February, 1648), 403-404.

${ }^{24}$ The Relation of the Unjust Proceedings Against Captaine Burley, paragraphs 6 and 7.

${ }^{25}$ Ibid, paragraphs $45-47$.

${ }^{26} \mathrm{PA}, \mathrm{HL} / \mathrm{PO} / \mathrm{JO} / 10 / 1 / 285$.

${ }^{27}$ Ibid.

${ }^{28}$ LJ, xi, 84 (7 July, 1660).

${ }^{29}$ Daybell, "Scripting a Female Voice”, 3-22; Hudson, "Negotiating for Blood Money”, 153; Thorne, "Women's Petitionary Letters", 27-29.

${ }^{30}$ Lacey, The Cult of King Charles, 77, 96.

${ }^{31}$ The Relation of the Unjust Proceedings Against Captaine Burley; True Relation of the Suffering of Captaine John Burleigh. For royalist martyrology during the 1650s, particularly in relation to Charles I, see Lacey, The Cult of King Charles, chapters 3 and 4.

${ }^{32}$ Donagan, War in England, 397-398; Ashton, Counter-Revolution, 408-409.

${ }^{33}$ Hutton, "Capel, Arthur (d. 1649)".

${ }^{34} \mathrm{PA}, \mathrm{HL} / \mathrm{PO} / \mathrm{JO} / 10 / 1 / 287 / 48$.

${ }^{35} \mathrm{PA}, \mathrm{HL} / \mathrm{PO} / \mathrm{JO} / 10 / 1 / 285$.

${ }^{36}$ Callow, "The Limits of Indemnity", 201; Walker, "Military Activities of Charlotte De La Tremouille", 62-63.

${ }^{37} \mathrm{PA}, \mathrm{HL} / \mathrm{PO} / \mathrm{JO} / 10 / 1 / 287 / 48$.

${ }^{38}$ For a full account of the royalist surrender at Colchester see Donagan, War in England, 357-358, 397-398.

${ }^{39}$ Ibid., 397-398; A Perfect Diurnal (5-12 February 1648); A Perfect Diurnall (12-19 February 1648); A Perfect Diurnall (19-26 February 1648); A Perfect Diurnall (5-12 March 1648).

${ }^{40}$ A Perfect Diurnall (12-19 February, 1648), 27.

${ }^{41} \mathrm{PA}, \mathrm{HL} / \mathrm{PO} / \mathrm{JO} / 10 / 1 / 287 / 48$.

${ }^{42}$ The National Archives [TNA], PCC PROB 11/303/317.

${ }^{43} \mathrm{PA}, \mathrm{HL} / \mathrm{PO} / \mathrm{JO} / 10 / 1 / 287 / 48$.

${ }^{44}$ Several Speeches of Duke Hamilton, Henry Earl of Holland, and Arthur Lord Capel, 37.

${ }^{45}$ Klemp, "Execution Ritual”, 323-345; Sharpe, “"Last Dying Speeches"”, 144-167.

${ }^{46}$ King Charls His Speech, 5.

${ }^{47}$ Complete Collection of State Trials, iv, 1238.

48 The Colchester Spie; Donagan, War in England, 344-347.

49 Divers Remarkable Passages, 10.

${ }^{50}$ Hughes, Gender and the English Revolution, 48; Donagan, War in England, pp. 398-399; CJ, vi, $203-204$ (7 May, 1649).

${ }^{51}$ Complete Collection of State Trials, v, 883-907; Underdown, Royalist Conspiracy in England, 208, 211-212.

${ }^{52}$ Peacey, "Hewitt, John (d. 1658)"; Hast, "State Treason Trials", 37-53. 
${ }^{53}$ Peacey, "Hewitt, John".
${ }^{54} \mathrm{PA}, \mathrm{HL} / \mathrm{PO} / \mathrm{JO} / 10 / 1 / 287$

${ }^{55} \mathrm{Ibid}$

${ }^{56} C J$, viii, 27 (15 May, 1660).

${ }^{57}$ The Humble Petition of Dame Mary Hewytt.

${ }^{58}$ Complete Collection of State Trials, v, 908; Dr John Hewytts Ghost, 18.

${ }^{59}$ Crawford, "“Charles Stuart, that Man of Blood"', 41-61; Baskerville, "Blood Guilt in the English Revolution", 181-202

${ }^{60}$ Peacey, Print and Public Politics, 276.

${ }^{61}$ Porter, Roberts and Roy, The Diary and Papers of Henry Townshend, 279.

${ }^{62}$ Ibid; See also Cust, "News and Politics", 60-90. Mary was not the only widow to utilise the medium of print. On 15 June the petition of Arundel Penruddock, wife of John Penruddock, was read in the Commons. As in the case of Mary, this supplication preceded the submission of a manuscript petition presented to the Lords. See The Humble Petition of Arundell Penruddock; CJ, viii, 64 (15 June, 1660).

${ }^{63}$ Oldridge, "Wright, Robert (1560-1643)"; Sherwood, The Civil War in the Midlands, 63; Matthews, Walker Revised, 4.

${ }^{64}$ Malbon, A Breefe \& True Relacon, 74-75.

${ }^{65}$ McKenna, The Letter Book of Sir William Brereton, 68-69.

${ }^{66}$ Malbon, A Breefe and True Relacon, 75.

${ }^{67} \mathrm{PA}, \mathrm{HL} / \mathrm{PO} / \mathrm{JO} / 10 / 1 / 296$; Morrill, "Brereton, Sir William (1604-1661)".

${ }^{68} \mathrm{PA}, \mathrm{HL} / \mathrm{PO} / \mathrm{JO} / 10 / 1 / 287$.

${ }^{69}$ The Humble Petition of Martha Hatt.

${ }^{70}$ O’Dowd, "Women and War in Ireland", 91-111.

${ }^{71}$ The Humble Petition of Martha Hatt, 4. For a discussion on debentures during the civil wars see Gentles, "The Sales of Crown Lands", 614-635.

${ }^{72}$ Clarke, "Jones, Sir Theophilus (d. 1685)"; CJ, vii, 779 (15 September, 1659).

${ }^{73} \mathrm{PA}, \mathrm{HL} / \mathrm{PO} / \mathrm{CO} / 7 / 1 ; \mathrm{HL} / \mathrm{PO} / \mathrm{JO} / 10 / 1 / 294$.

${ }^{74} \mathrm{PA}, \mathrm{HL} / \mathrm{PO} / \mathrm{CO} / 7 / 3$; Hart, Justice Upon Petition, 223-224.

${ }^{75}$ Dorchester reported from the Committee on 7 July, 19 July and 23 July 1660. LJ, xi, 84, 97, 103.

${ }^{76}$ Swatland, The House of Lords, 82.

${ }^{77} \mathrm{PA}, \mathrm{HL} / \mathrm{PO} / \mathrm{CO} / 7 / 1 ; \mathrm{HL} / \mathrm{PO} / \mathrm{CO} / 7 / 3$.

${ }^{78} \mathrm{Ibid}$.

${ }^{79} \mathrm{PA}, \mathrm{HL} / \mathrm{PO} / \mathrm{CO} / 7 / 3$.

${ }^{80} \mathrm{LJ}, \mathrm{xi}, 81$ (3 July, 1660).

${ }^{81} \mathrm{PA}, \mathrm{HL} / \mathrm{PO} / \mathrm{CO} / 7 / 3$.

${ }^{82}$ Ibid.

${ }^{83}$ Ibid.

${ }^{84}$ Cobbett, The Parliamentary History of England, iv, 88-90.

${ }^{85}$ LJ, xi, 118-119 (6 August, 1660); Hart, Justice Upon Petition, 237.

${ }^{86} \mathrm{PA}, \mathrm{HL} / \mathrm{PO} / \mathrm{DC} / \mathrm{CP} / 1$, i.

${ }^{87}$ Schoenfeld, The Restored House of Lords, 191.

${ }^{88} \mathrm{LJ}$, xi, 136 (21 August, 1660).

${ }^{89}$ Venning, "Lisle, John (d. 1664)".

${ }^{90}$ For the government's treatment of these men at the Restoration see their relevant entries on ODNB.

${ }^{91}$ Peacey, "Mildmay, Henry (c.1594-1664/5?)"; Helms and Watson, "Hildesley, John (c.1598-1681)".

${ }^{92}$ Zaller, "Wilde, John (1590-1669)"; Button, "Royalist Women Petitioners", 57.

${ }^{93}$ Calendar of State Papers Domestic, 1660-1661, 430.

${ }^{94}$ Hutton, "Capel, Arthur".

${ }^{95}$ Calendar of State Papers Domestic, 1660-1661, 523; Peacey, “Hewitt, John”; TNA, SP 29/113/129.

${ }^{96}$ Oldridge, "Wright, Robert".

${ }^{97}$ Harris, Restoration, 48.

${ }^{98}$ Appleby, "The Restoration County Community", 106.

${ }^{99}$ Hopper, "The Widows and Orphans of Parliament's Military Commanders". I am grateful to Andrew Hopper for allowing me to read this unpublished paper.

${ }^{100}$ Hart, Justice Upon Petition, 238; Harrington, “Transitional Justice Theory”, 68-83.

${ }^{101}$ TNA, SP 29/52/28-29. For an account of Hudson's death see Hopper, “The Reluctant Regicide?", 43-44.

${ }^{102}$ Laurence, Parliamentary Army Chaplains, 125; TNA, SP 29/52/30.

${ }^{103}$ TNA, SP 29/89/37. See also the 1663 petition of Mary Holyland for compensation from the estates of Colonels Edmund Harvey and Henry Martin, who plundered her estate to the value of $£ 2000$ during the civil wars. TNA, SP 29/89/36. 
${ }^{104}$ Schwoerer, "Women and the Glorious Revolution", 200-201.

${ }^{105}$ The Humble Petition of the Widdows and Fatherless Children in the West of England.

\section{Bibliography}

Manuscript Sources

Parliamentary Archives

$\mathrm{HL} / \mathrm{PO} / \mathrm{JO} / 10 / 1 / 285-287,294,296$.

$\mathrm{HL} / \mathrm{PO} / \mathrm{CO} / 7 / 1,3$.

$\mathrm{HL} / \mathrm{PO} / \mathrm{DC} / \mathrm{CP} / 1$.

The National Archives

SP 29.

PCC PROB 11.

$\underline{\text { Printed sources and calendars }}$

Beheaded, Dr John Hewytts Ghost Pleading, yea crying for Exemplarie Justice Against the Arbitrarie, Unexamples Injustice of his late Judges and Executioners in the New High Commission, or Court of Justice, sitting in Westminster-Hall. London, 1659.

Browning, A., ed. English Historical Documents: Volume 8: 1660-1714. London: Eyre \& Spottiswoode, 1953.

The Colchester Spie: Truly Informing the Kingdome of the Estate of that Gallant Town, and the Attempts of Fairfax Against It. 1648.

A Designe by Captain Barley, and Others, to Surprize Carisbrook Castle. London, 1648.

Divers Remarkable Passages Concerning the Originall and Progresse of the Present Great Action in Essex. London, 1648.

Green, M, ed. Calendar of State Papers, Domestic Series, Charles II. 1660-1661. London: HMSO, 1860.

Howell, T, ed. Cobbett's Complete Collection of State Trials: Volumes 4 and 5. London: R. Bagshaw, 1809-1810.

The Humble Petition, Appeal, Proposals, and Oppressed Cry for Impartial and Speedy Justice, of Martha Hatt alias Arundel, the Relict and Sole Executrix of Cornet Simon Hatt. London, 1659.

The Humble Petition of Arundell Penruddock, Widdow, Late Wife of John Penruddock, Esquire, Deceased. London, 1660.

The Humble Petition of Dame Mary Hewytt, Late Wife of John Hewytt, Doctor in Divinity. London, 1660.

The Humble Petition of the Widdows and Fatherless Children in the West of England, Presented to this Present Convention. 1689.

Journal of the House of Commons: Volumes 6, 7, 8, 1648-1667. London: HMSO, 1802.

Journal of the House of Lords: Volume 11, 1660-1666. London: HMSO, 1767-1830.

King Charls His Speech Made upon the Scaffold at Whitehall-Gate. London, 1649.

Malbon, T. A Breefe \& True Relacon of all Suche Passages \& Things as Happened \& Weire Donne in and Aboute Namptwich... Scythens the Xth of August 1642 (1651). In Memorials of the Civil War in Cheshire and the Adjacent Counties, edited by J. Hall. Lancashire and Cheshire Record Society, vol. 19. Cheshire, 1889. 
McKenna, J, ed. A Journal of the English Civil War: The Letter Book of Sir William Brereton, spring 1646. Jefferson: McFarland, 2012.

A Perfect Diurnall of Some Passages in Parliament. Nos. 289-291, 293: 5-12 February, 12-19 February, 19-26 February, 5-12 March. London, 1649.

Perfect Occurrences of Every Daie Iournall in Parliament. No. 58: 4-11 February. London, 1648.

Porter, S. Roberts, S. and Roy, I., eds. The Diary and Papers of Henry Townshend, 1640-1663. Worcestershire Historical Society, vol. 25. Bristol: 4word, 2014.

Raithby, J, ed. Statutes of the Realm: Volume 5: 1628-1680. London: George Ayre and Andrew Strahan, 1819.

Scott, W, ed. Original Memoirs, Written During the Great Civil War; Being the Life of Sir Henry Slingsby, and Memoirs of Captain Hodgson. Edinburgh: A. Constable, 1806.

The Relation of the Unjust Proceedings Against Captaine Burley at Winchester And of his Magnanimous and Christian suffering. 1648.

A Sermon Preached at the Funerall of The Right Honourable The Most Excellent Lady, The Lady Elizabeth Capell. London, 1661.

The Several Speeches of Duke Hamilton Earl of Cambridg, Henry Earl of Holland, and Arthur Lord Capel, Upon the Scaffold and Immediately Before their Execution. London, 1649.

True and Brief Relation of the Araignment, Condemnation and Suffering of Captaine John Burleigh. 1648.

Winstanley, W. The Loyall Martyrology. London, 1665.

\section{$\underline{\text { Secondary sources }}$}

Appleby, D. "The Restoration County Community: A Post-Conflict Culture". In The County Community in Seventeenth-Century England and Wales, edited by J. Eales and A. Hopper, 100-124. Hertford: Hertfordshire University Press, 2012.

Appleby, D. "Unnecessary Persons? Maimed Soldiers and War Widows in Essex, 1642-62.” Essex Archaeology and History 32 (2001): 209-221.

Appleby, D. "Veteran Politics in Restoration England, 1660-1670." The Seventeenth Century 28, no. 3 (2003): 323-342.

Ashton, R. Counter-Revolution: The Second Civil War and its Origins, 1646-1648 (New Haven: Yale University Press, 1994.

Baskerville, S. "Blood Guilt in the English Revolution." The Seventeenth Century 8, no. 2 (1993): 181-202.

Button, A. "Royalist Women Petitioners in South-West England, 1655-62." The Seventeenth Century 15, no. 1 (2000): 53-66.

Callow, J. "The Limits of Indemnity: The Earl of Derby, Sovereignty and Retribution at the Trial of William Christian, 1660-1663." The Seventeenth Century 15, no. 2 (2000): 199-216.

Cobbett, W. The Parliamentary History of England: from the Norman Conquest, in 1066, to the Year 1803. 36 vols. London: Thomas Hansard, 1808.

Crawford, P. “"Charles Stuart, that Man of Blood””. Journal of British Studies 16, no. 2 (1977): 41-61.

Cust, R. "News and Politics in Early Seventeenth-Century England.” Past and Present 112, no. 1 (1986): 60-90. 
Daybell, J. "Scripting a Female Voice: Women's Epistolary Rhetoric in Sixteenth-Century Letters of Petition." Women's Writing 13, no. 1 (2006): 3-22.

Donagan, B. War in England 1642-1649. Oxford: Oxford University Press, 2008.

Farr, D. Major-General Thomas Harrison: Millenarianism, Fifth Monarchism and the English Revolution, 16161660. Farnham: Ashgate, 2014.

Gentles, I. "The Sales of Crown Lands During the English Revolution." Economic History Review 26, no. 4 (1973): 614-635.

Harrington, M. "Transitional Justice Theory and Reconciling Civil War Division in English Society, circa 16601670." In Civilians and War in Europe, 1618-1815, edited by E. Charters, E. Rosenhaft and H. Smith, 68-83. Liverpool: Liverpool University Press, 2012.

Harris, T. Restoration: Charles I and his Kingdoms. London: Penguin, 2006.

Hart, J. Justice Upon Petition: The House of Lords and the Reformation of Justice 1621-1675. London: HarperCollins, 1991.

Hast, A. "State Treason Trials During the Puritan Revolution, 1640-1660." The Historical Journal 15, no. 1 (1972): 37-53.

Healey, J. The First Century of Welfare: Poverty and Poor Relief in Lancashire, 1620-1730. Woodbridge: Boydell \& Brewer, 2014.

Hopper, A. “'To Condole With Me on the Commonwealth's Loss': the widows and orphans of parliament's military commanders" (forthcoming).

Hopper, A. "The Farnley Wood Plot and the Memory of Civil War in Yorkshire." The Historical Journal 45, no. 2 (2002): 281-303.

Hopper, A. "The Reluctant Regicide? Thomas Wayte and the Civil Wars in Rutland.” Midland History 39, no. 1 (2014): 36-52.

Hudson, G. "Negotiating for Blood Money: War Widows and the Courts in Seventeenth-Century England." In Women, Crime and the Courts in Early Modern England, edited by J. Kermode and G. Walker, 146-169. London: UCL Press, 1994.

Hughes, A. Gender and the English Revolution. Abingdon: Routledge, 2012.

Hutton, R. The Restoration: A Political and Religious History of England and Wales 1658-1667. Oxford: Clarendon Press, 1985.

Jones, J. The Royal Prisoner: Charles I at Carisbrooke. London: Lutterworth, 1965.

Klemp, P. “'I Have Been Bred Upon the Theatre of Death, and Have Learned That Part': The Execution Ritual During the English Revolution.” The Seventeenth Century, 26, no. 2 (2011): 323-345.

Lacey, A. The Cult of King Charles the Martyr. Woodbridge: Boydell \& Brewer 2003.

Laurence, A. Parliamentary Army Chaplains, 1642-1651. Woodbridge: Boydell, 1990.

Matthews, A. Walker Revised: Being a Revision of John Walker's Sufferings of the Clergy during the Grand Rebellion 1642-1660. Oxford: Clarendon Press, 1948.

Miller, J. After the Civil Wars: English Politics and Government in the Reign of Charles II. Harlow: Longman, 2000. 
O’Dowd, M. "Women and War in Ireland in the 1640s." In Women in Early Modern Ireland, edited by M. MacCurtain and M. O’Dowd, 91-111. Edinburgh: Edinburgh University Press, 1991.

Peacey, J. Print and Public Politics in the English Revolution. Cambridge: Cambridge University Press, 2013.

Robert, S. "Public or Private? Revenge and Recovery at the Restoration of Charles II" Historical Research 59, no. 140 (1986): 172-188.

Rosenthal, J. "Other Victims: Peeresses as War Widows, 1450-1500." History 72, no. 235 (1987): 213-230.

Schoenfeld, M. The Restored House of Lords. The Hague: Mouton, 1967.

Schwoerer, L. "Women and the Glorious Revolution.” Albion 18, no. 2 (1986): 195-218.

Seaward, P. The Restoration, 1660-1688. Basingstoke: Macmillan, 1991.

Sharpe, J. “'Last Dying Speeches': Religion, Ideology and Public-Execution in Seventeenth-Century England." Past and Present 107, no. 1 (1985): 144-167.

Sherwood, R. The Civil War in the Midlands 1642-1651. Stroud: Alan Sutton, 1992.

Swatland, A. The House of Lords in the Reign of Charles II. Cambridge: Cambridge University Press, 1996.

Thorne, A. "Women's Petitionary Letters and Early Seventeenth-Century Treason Trials." Women's Writing 13, no. 1 (2006): 23-43.

Underdown, D. Royalist Conspiracy in England, 1649-1660. New Haven: Yale University Press, 1960.

Walker, K. "The Military Activities of Charlotte De La Tremouille, Countess of Derby, During the Civil War and Interregnum." Northern History 38, no. 1 (2001): 47-64.

Worthen, H. "Supplicants and Guardians: The Petitions of Royalist Widows during the Civil Wars and Interregnum, 1642-1660." Women's History Review special edition, 'Home Fronts, Gender War and Conflict' (2016): 1-13.

\section{$\underline{\text { Online sources }}$}

Clarke, A. “Jones, Sir Theophilus (d. 1685)." Oxford Dictionary of National Biography, Oxford University Press, published online 2006. http://www.oxforddnb.com/view/article/15084.

Helms, M. and Watson, P. “Hildesley, John (c.1598-1681).” Accessed December 42016.

http://www.historyofparliamentonline.org/volume/1660-1690/member/hildesley-john-1598-1681.

Henderson, T and Trombley, S. "Burley, John (d. 1648)." Oxford Dictionary of National Biography, Oxford University Press, published online 2010. http://www.oxforddnb.com/view/article/4035.

Hutton, R. "Capel, Arthur, first Baron Capel of Hadham (1604-1649)." Oxford Dictionary of National Biography, Oxford University Press, published online 2006. http://www.oxforddnb.com/view/article/4583.

Morrill, J. "Brereton, Sir William, first baronet (1604-1661)." Oxford Dictionary of National Biography, Oxford University Press, published online 2013. http://www.oxforddnb.com/view/article/3333.

Oldridge, D. "Wright, Robert (1560-1643)." Oxford Dictionary of National Biography, Oxford University Press, 2004. http://www.oxforddnb.com/view/article/30055.

Peacey, J. “Hewitt, John (bap. 1614, d. 1658)." Oxford Dictionary of National Biography, Oxford University Press, 2004. http://www.oxforddnb.com/view/article/13147. 
Peacey, J. “Mildmay, Henry (c.1594-1664/5?).” Oxford Dictionary of National Biography, Oxford University Press, 2004. http://www.oxforddnb.com/view/article/18695.

Venning, T. “Lisle, John (1609/10-1664).” Oxford Dictionary of National Biography, Oxford University Press, published online 2006. http://www.oxforddnb.com/view/article/16756.

Zaller, R. "Wilde, John (1590-1669).” Oxford Dictionary of National Biography, Oxford University Press, 2004. http://www.oxforddnb.com/view/article/29399. 